\title{
geosciences
}

ISSN 2076-3263

www.mdpi.com/journal/geosciences

Article

\section{Geoscience of the Built Environment: Pollutants and Materials Surfaces}

Carlos Alves ${ }^{1, *}$ and Jorge Sanjurjo-Sánchez ${ }^{2}$

1 Centre of Geological Research, Management and Valorisation of Resources (CIG-R), University of Minho/School of Sciences, University of Minho, Campus de Gualtar, 4710-057 Braga, Portugal

2 Instituto Universitario de Xeoloxía “Isidro Parga Pondal", Universidade da Coruña/Edificio Servizos Centrais de Investigación, Universidade da Coruña, Campus de Elviña, 15071 A Coruña, Spain; E-Mail: jsanjurjo@udc.es

* Author to whom correspondence should be addressed; E-Mail: casaix@dct.uminho.pt; Tel.: +351-253604300; Fax: +351-253678206.

Received: 9 December 2011 / Accepted: 18 December 2011 / Published: 20 December 2011

\begin{abstract}
An overview of issues with environmental relevance that arise from the interaction between pollutants and surfaces of the built environment is presented in this paper. Two broad perspectives are considered: decay of materials and recording of pollution characteristics. In relation to the former, we consider the possible implications on human activities restrictions, materials and morphological options, consumption of resources and release of pollutants resulting from the alteration of materials, conservation and restoration procedures. In terms of pollution recording, the interest of the stony materials as passive monitors of pollution, the question of heterogeneous conditions on buildings and the interest of qualitative and quantitative studies are highlighted. The importance of longitudinal studies on new and cleaned surfaces is considered, both for the understanding of materials decay and for the assessment of pollution conditions. The use of tracers to record the characteristics of pollution sources, interaction with materials and pathways of pollutants is also discussed. Finally, some recommendations are presented, based on the issues discussed on this paper that might be relevant for environmental management programs, including environmental education.
\end{abstract}


Keywords: alteration; stony materials; built environment; environmental studies; pollution monitoring

\section{Introduction}

Materials are an essential part of our culture and way of life being applied in a great diversity of surfaces of the built environment, from extensive outdoors walls to kitchen countertops. As has been recognized for a long time, they experience transformations after emplacement (Herodotus, Vitruvius and the Bible refer to alterations of materials). These alterations are related to characteristics of the materials and conditions of application, including environmental conditions and buildings.

Diverse pollutants can interact with surfaces in the built environment causing unwanted alterations and leaving marks of these interactions. In this paper, we attempt to present an overview of the possible relevance of the study of these interactions for environmental policy, regarding both impact on materials (including materials with cultural value) and the use of decay features such as sources of information on pollution.

The following two main sections of the paper represent different perspectives in relation to the built environment and pollutants. In the next section environmental issues arising from the study of the behavior of materials applied in the built environment are considered, both from the perspective of the conservation of the old (cultural heritage), applications on new constructions and building materials as sources of pollutants. This is followed by a discussion on the potentialities and problems on the use of built surfaces as records of pollution. The paper ends with some final considerations and recommendations based on the contents of the previous sections.

\section{Decay of Materials}

Extrinsic agents can affect materials' surfaces causing alterations of their initial characteristics, either from changes in the initial substances, accretion of matter or erosive loss, resulting in macroscopic evidences. A detailed classification of the features resulting from alteration of stony materials (that can be applied to other materials) is found in [1]. These processes affect the generality of materials, namely porous materials such as stony materials [2-4] and woods [5,6], but also metals [7-9], polymers [10,11], glass [12,13], paints [14,15] and paintings [16-18] in both very ancient and recent works.

In the case of alteration of building materials that are elements of cultural heritage, conservation would comprise measures for reduction of the decay process of building materials. When the processes are linked to pollutants resulting from antrophogenic activities, these measures could include reduction of emissions from vehicles and industry which might even imply the closure of roads and facilities (the impact of vibrations from circulating vehicles must also be considered). Favrel and Hecq [19] include the impact on buildings in their assessment of costs related to air traffic. Watt et al. [20] discuss the possible implications of the effects of pollution on buildings for the definition of air quality standards. As another example, the Portuguese municipal assembly of Batalha, in Portugal, recently expressed concern for the possible impact of increasing vehicle traffic near the Batalha's monastery. The 
circulation and access of people to museums and cultural elements, as well as climatic options, activities and materials may also impact such places of interest [21-24].

In this context, it is essential to assess the real impact of decay processes. For example, biological colonization can have a marked visual impact leading to visual hindering of decorative elements (and therefore it could obliterate its cultural value); however its impact in terms of physical transformation and material loss is usually minimal. Several studies have attempted to establish relations between decay of materials and pollution conditions through laboratory studies aiming to define damage or dose-response functions [9,13,20,25-28]. However, the application of these studies to actual structures is hindered by questions regarding size and time effects as well as the multiplicity of agents that are involved and the complexity of the interactions. There have been fewer studies comparing observed decay of materials in actual structures to the characteristics of the pollution load in the area (e.g., as was done by Nord et al. [29]).

The evaluation of the decay of a material can be a matter of great controversy as is illustrated in Mostafavi and Leatherbarrow [30] where several points of view are considered, including the perspective that weathering can be seen as productively modifying a building over time. One can even find examples of intentional weathering [30-32]. The assessment of the alteration of a built element should consider intensity and extension (see Fitzner and Heinrichs [1]), the distribution of alteration features and the age of the element. For example irregular straining can be considered as dirt or soiling [30,33] especially in recent constructions (see Figure 1), while a generalized biological coating in older constructions can be considered as "patina" that mark the passage of time (for further considerations see Mostafavi and Leatherbarrow [30] and Kirkwood [31]).

Figure 1. Irregular staining of limestone applied on a recent construction.

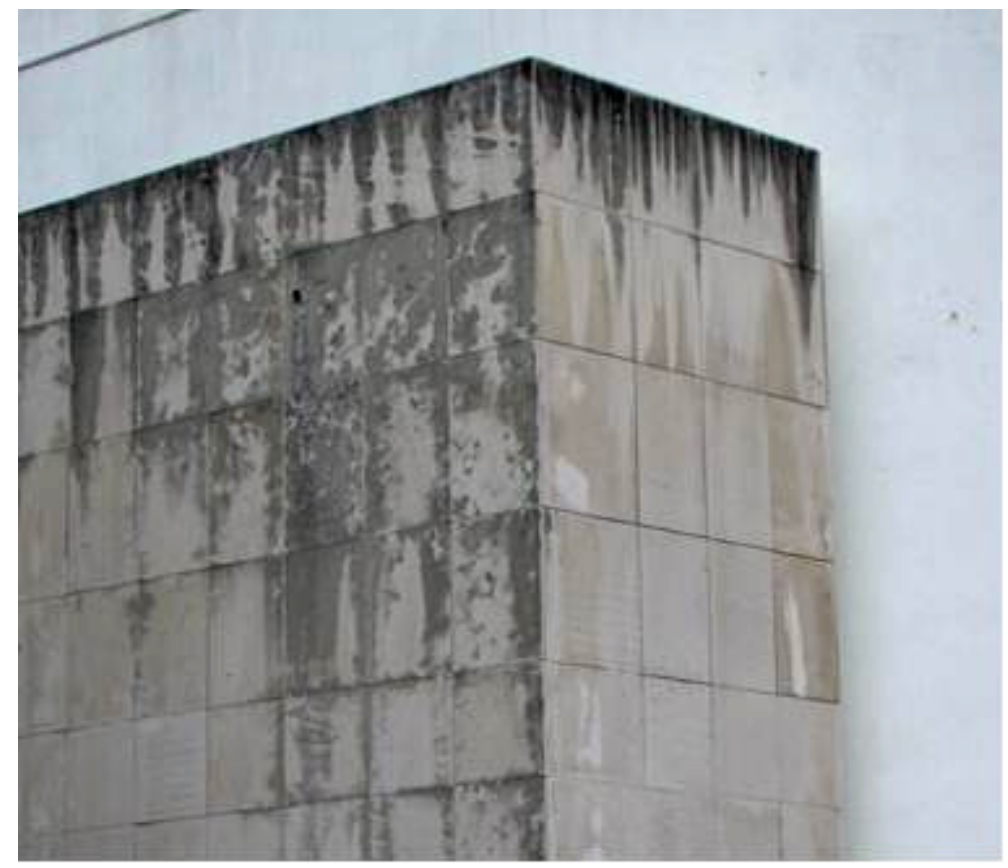

Besides the obvious question of the balance between the value of the cultural elements and the consequences of the proposed restrictions, there is the more complex question of the assessment of the links between decay and agents and the even more complex questions of risk assessment as well as of 
the effectiveness of the measures. Epidemiological observational studies of the alteration of materials can contribute significantly in this regard. An initial consideration that must be addressed is the possible diagnostic value of decay features. The identification of pollution sources that affect the built heritage suffers frequently from the problem of equifinality that affects many studies in the natural sciences (see discussion in Turkington and Paradise [34]). While it is hardly possible to relate a specific alteration feature to a specific pollution source, the study of the spatial distribution of decay features and substances (minerals, chemical elements, ions, isotopes) could help to pinpoint pollution sources. The identification of pollution sources would be important for planning of intervention measures.

Some records of the characteristics, effects and pathways of pollutants in the built environment have been obtained by using geochemical tracers used with variable results. In particular, some chemical compounds can be used as tracers of pollution. Regarding particulate tracers, some of them are useful to record the effect of atmospheric pollution. Some atmospheric particles (such as N- or S-rich particles) can react with building materials to originate secondary compounds, products of decay. Other particles can be deposited on the materials' surface, but some of them act as catalysts of sulfation reactions of atmospheric $\mathrm{SO}_{2}$ with Ca-rich building materials [2].

Some other common gaseous, dissolved and particulate pollutants are sulfur, nitrogen, and carbon oxides. They are key components involved in the deterioration of building materials that cause the deposition of crystallization of neoformation minerals. Stable isotopes of sulfur, oxygen and carbon have been used in studies of migration of water and pollutants into the building system and interaction with the building materials [35-38]. Stable isotopes of $\mathrm{N}$ and $\mathrm{H}$ and radioactive isotopes are scarcely used as tracers in the built environment but, as is discussed, they could provide useful information on the pathways and sources of pollutants, as in other cases such as atmospheric pollution dispersion, hydrological and geochemical studies in nature (see [39] for discussion).

Given the possible impact of the proposed measures, it is essential to distinguish contribution of presently acting pollution source from the effects related to pollution events that occurred in the past, a distinction that can be extremely hard to assess in historical constructions since there are interactions of pollution agents over time on the built surfaces. This is illustrated in Figure 2 where several emissions of pollutants are considered as well as different sampling times. In the simplest case, admitting that there is no loss from the system, that deposition equals emission, and that the pollution effects act in a cumulative way, the pollution assessed at a given moment is the sum of the integrals of the pollution emission curve up to that time. In the case illustrated in Figure 2, the later the sampling the higher the contents and the higher the multiplicity and complexity of pollution. Additionally, it has been observed that pollutants deposits might evolve with time requiring more aggressive cleaning techniques [40]. The interaction between pollutants and of them with the substrate, and issues related to transport and deposition, would also need to be considered in real cases. 
Figure 2. Simplified representation of pollutants deposition on a surface of the built environment. Four moments of sampling are considered. Under undisturbed conditions (S1-3) earlier sampling corresponds to more specific pollution conditions. In S4 only the pollutants deposited after cleaning are assessed, (admitting the success of the cleaning procedures and that no residue of cleaning substances remains). Prepared with OpenOffice 3.

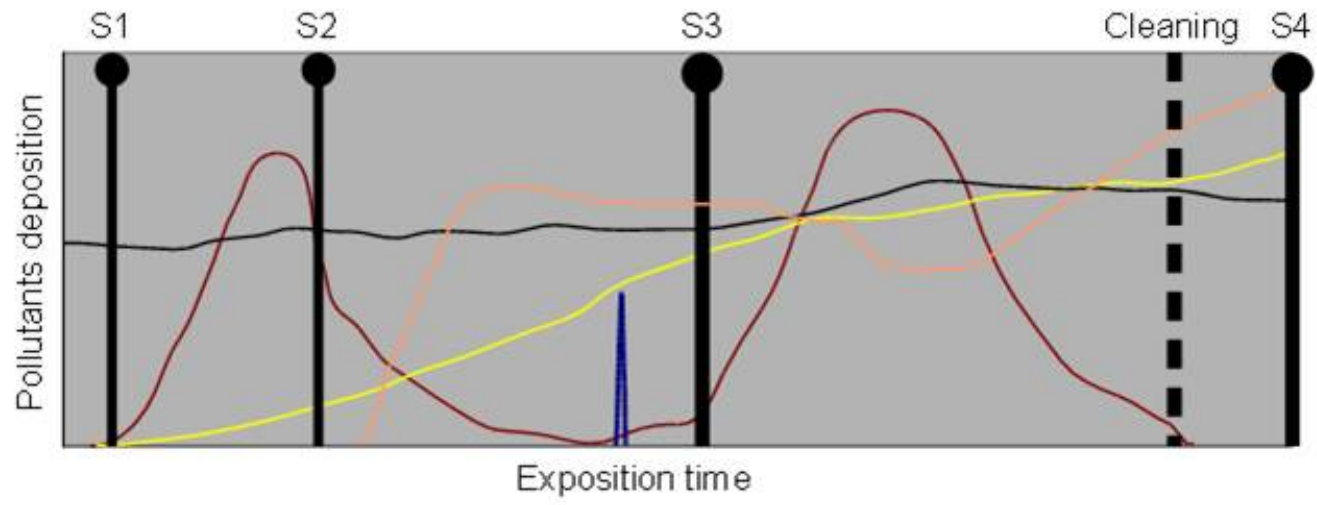

The previous paragraph illustrated the importance of understanding the relationship between pollution sources and decay processes, of studying new works located in the same area as the affected element and to develop longitudinal studies of materials surface. Considering this aim, longitudinal studies could be carried out on old and new materials surfaces as well as on cleaned surfaces. In Figure 2 cleaning is also taken into consideration. In the illustrated example, and admitting a 100\% effective cleaning operation that leaves no residue, the system at S4 would present only the pollutants that were deposited after cleaning. Higher rates of decay after cleaning have been observed [41] and cleaned surfaces could constitute enhanced sampling elements. Periodically cleaned surfaces could be important instances for longitudinal studies regarding the action of pollutants. In this last case, however, it is necessary to assert the effects of the cleaning, namely whether there is a "reset" of the system, the permanence of residual amounts of pollutants or even the introduction of new substances.

Cleaning and other conservation operations could also introduce restrictions on normal circulation of people and vehicles, causes spending of resources (namely water) and, more worrying, environmental risks, namely associated with some of the substances that are used $[22,42,43]$ and the introduction of pollutants in the treated materials $[42,44]$. The issue of resources consumption, materials and energy, is a current concern for conservation installations such as museums $[45,46]$. The need for repeated maintenance would imply additional costs and can have an impact on the materials $[20,41]$. The previsions of decay rates can be used to estimate the periodicity of cleaning [47] and simulations of performance-degradation models have been considered in the discussion of maintenance budgeting [48]. Conservation intervention is strongly linked to diagnostics studies in order to define the measures that are adjusted to the problem and avoid excessive use of resources.

Another environmental issue related to cultural heritage is the substitution of decayed materials for new materials, an operation that would imply consumption of new substances for the preparation of the new materials, with the associated financial and environmental costs, as well as environmental risks associated with the extraction operations. This links these previous considerations regarding cultural heritage with the more general issue of materials durability, which is also relevant for new works. 
Therefore, the identification and selection of materials that have higher durability would promote required performance for a longer time and decrease the impact associated with these two aspects (expenditure of resources and release of contaminants). However, this must be balanced with the possible environmental costs of extraction of these more durable materials. The need to use stones with higher durability could imply measures such as the preservation of quarries of stones with higher durability value (with consequences for territory management). For example in Portuguese legislation, the recognition of quality and value of a certain rock types has lead to definition of geological reserves with restriction on the kind of activities that can be developed. Another related issue is the consideration of materials making allowance for the environmental impact of its fabrication as well as its recycling capability [46].

Besides the intrinsic properties of materials, there are architectural options that can promote depreciation of the built surfaces. There are studies of computer simulation of weathering of materials in relation to morphological features $[49,50]$, an aspect that has been mostly considered in terms of virtual reality for applications such as videogames and movies. Certain characteristics of the built environment that promote infiltration or permanence of water could promote the development of decay features. Characteristics that promote or minimize alteration can be considered in the design of structures in order to minimize weathering processes [7,30,33,51-55].

There are important interrelations between studies of the old and of the new. Historical heritage elements could be important sources of information on the behavior of stones under real exposition conditions (in contrast to laboratory tests, perfectly controlled but limited in size, time and lacking the impact of interactions). The observations of the evolution of new constructions could be an important component for understanding decay of historical cultural heritage, following the old geology motto of "the present is the key to the past".

Another aspect related to alteration of building materials is the release of pollutants. Building materials can act as pollution sources affecting the surrounding environment (in relation to cementitious materials see [56]; regarding metallic materials several examples can be found in [57]). The release of substances from building materials can also affect those materials or other nearby materials. Pollutants from building materials can arise from the pore content such as soluble salts on natural rocks $[21,58,59]$ and in the case of cements in the initial stages of setting (for the main chemical characteristics of the pore solutions in initial stages of setting of cements see [60] and references therein). In the case of artificial materials prepared with water (such as mortars and pavements) the water that is used is also a potential source of pollutants [61]. In the context of epidemiological studies of materials decay, one needs to study the release of pollutants due to the alteration of the constituents of materials, as mentioned in relation to the weathering of constituents of natural stone, specially calcite [62-68] but also dolomite [69], silicates [70,71], iron sulfides [72-75] or oxides [76-79] and organic components ([80]; see also several references in [81]), constituents of set mortars [80,82,83] and metals corrosion [3]. These aspects could be considered in relation to the formulation of materials (and the control of chemical composition of different constituents) but also regarding the way they are applied on the built environment (architectural options).

Finally, one can note that there is currently research [84] that aims to develop new materials that interact actively with the surrounding environment ("metabolic materials"), promoting the preservation 
of the building from the action of exterior agents and the positive impacts of the building on the surrounding environment ("living architecture").

\section{Built Environment as Record of Pollution}

Elements of the built environment, since they react and fixate pollutants, have the potential to constitute records of the surrounding environment. This is a relatively common notion that is found, for example, when people refer to rust marks in metallic elements in regions near the sea. While the conditions of fixation of pollutants by humans and by materials surfaces have major differences, studies of surfaces can be valuable in the comparison of exposure conditions.

Alterations of surfaces can be easily detectable (namely by visual inspection) indicators of pollution. At an initial stage and in a qualitative perspective one can consider the possible information that can be gained from the occurrence of alteration features and its typology (for a developed proposal of weathering features typology see Fitzner and Heinrichs [1]). The recording value of decay forms for the study of pollution can be very different. In general terms, one can argue that fixation increases while erosion decreases the recording potential and, in that sense, the most valuable decay features for the characterization of the pollution load are coatings.

There is a great variety of coatings that develop as a consequence of the action of exogenous agents (absorption, reaction, deposition) and, hence, the presence of certain coatings might give general indications regarding the presence of pollutants. In general, soiling aspects constitute indicators of circulation of atmospheric particulate pollution (Figure 3). Coatings formed on façades can give qualitative information on the characteristics of the environment surrounding these buildings $[85,86]$.

Figure 3. Soiling deposits evidencing circulation of particles (b is an enlarged portion of a).
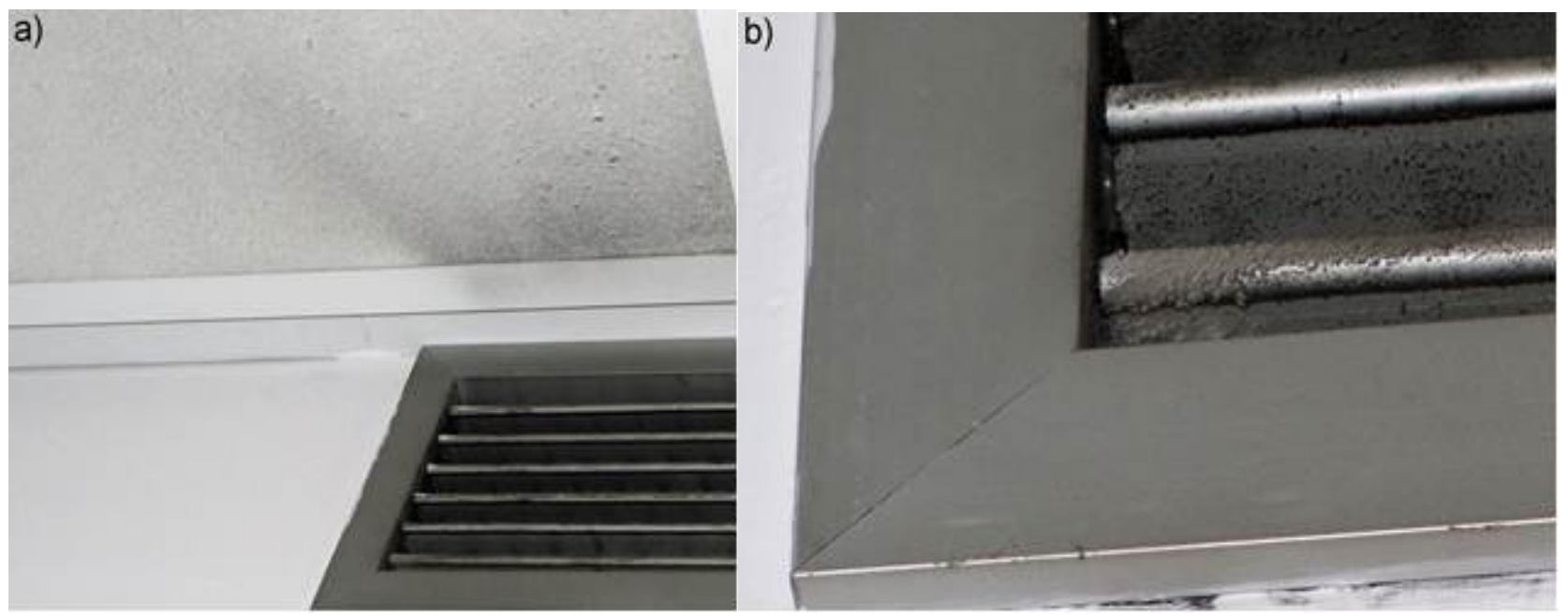

Simple dust deposits have been used for studies of pollution in outdoor and indoor locations [23]. On other, more complex, coatings, pollutants are fixated by organisms or by mineral aggregates. A (in)famous kind of coating related to mineral neoformations is the black crust, where gypsum aggregates fixate atmospheric particulate matter (Figure 4). In this case the gypsum aggregates (see Figure 4b) trapping atmospheric particles contribute to very evident visual features. Another type of widespread coating, especially in diverse modern constructions [87], are carbonate-rich coatings 
(Figure 5). and the possible environmental monitoring potential of this frequent type of coating, which is usually very stable after formation, remains underexplored (natural carbonate deposits with similar characteristics such as tufas has been used in environmental monitoring even in modern environments, see $[88,89])$.

Figure 4. Images of black crusts on granite buildings: (a) field observation; (b) scanning electron microscope observation showing gypsum aggregates.

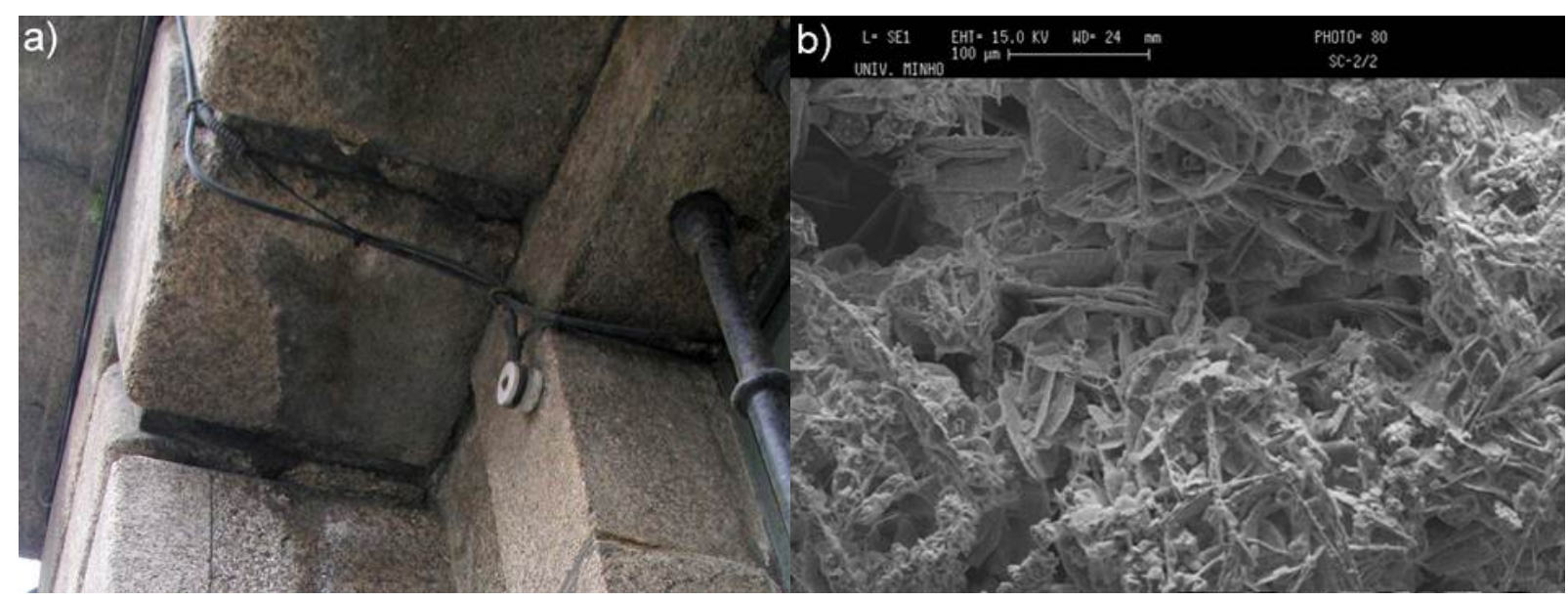

Figure 5. Example of carbonate crusts on granite stones.

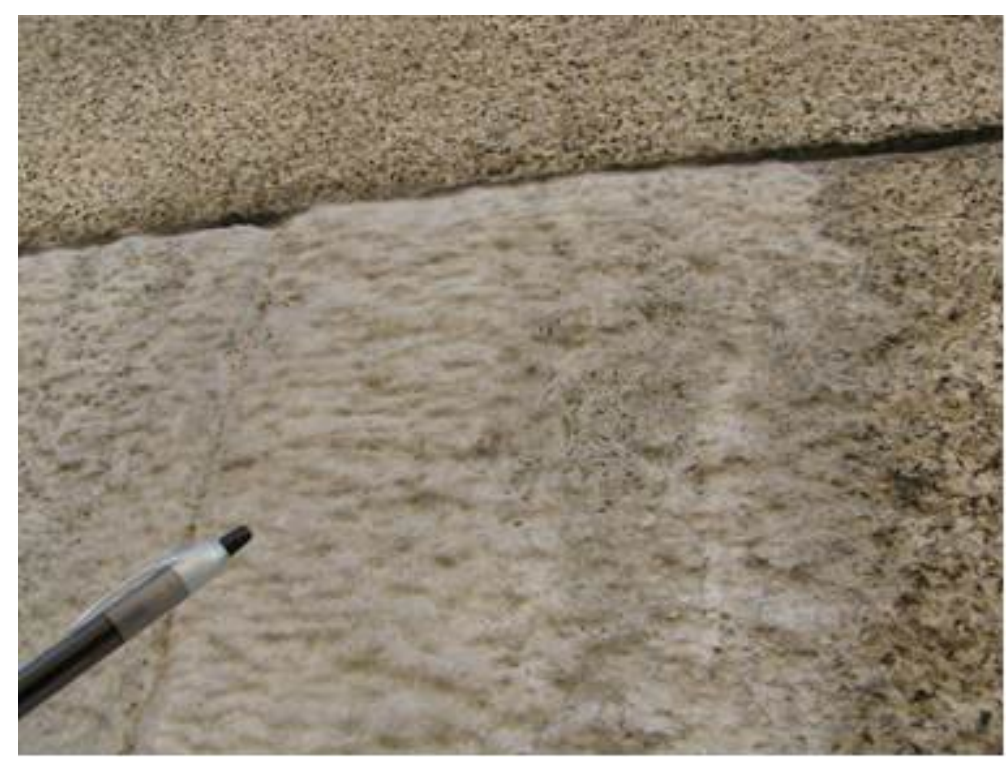

While it could be argued that the presence of erosive features indicates environmental aggressiveness, this could be less relevant from the ecological and human health perspectives. For example, water in its purest form can cause erosion of surfaces but this is not a matter of concern for humans and other organisms.

Another aspect related to the possible assessment of the effects of pollution is the distribution of decay features, considering both the regional distribution and frequency and also the distribution according to morphological characteristics of the built element. This last issue is especially relevant 
since it is essential to assess the heterogeneity of conditions for the development of decay features and hence the heterogeneity of recording conditions on the built environment.

Under favorable conditions (assuming homogeneous fixation conditions), patterns of distribution can also help to study patterns of circulation of pollutants both horizontally and vertically. However, the recording conditions on a given element can be highly heterogeneous depending on morphology, surface irregularity, moisture and orientation. Fixation of pollutants would be different on horizontal and vertical surfaces [90]. Even in a straight-faced wall there would be differential patterns of alteration ([91] see also Figure 1). Temperature and relative humidity variations control formation by condensation of moisture films that promote reaction between the substrate and gases and the fixation of particulate matter [92,93]. Sheltering conditions can greatly affect the fixation of pollutants in outside portions as is illustrated in Figure 6. The characteristics of the location of the built elements can also affect distribution of pollutants. In canyon streets there are higher concentrations of pollutants from traffic of vehicles near the ground while pollutants related to more distant sources, such as industrial sources at the outskirts of the towns, are more concentrated at the upper level [94-96].

Figure 6. Heterogeneous development of coatings related to architectural characteristics with clear predominance in sheltered portions.

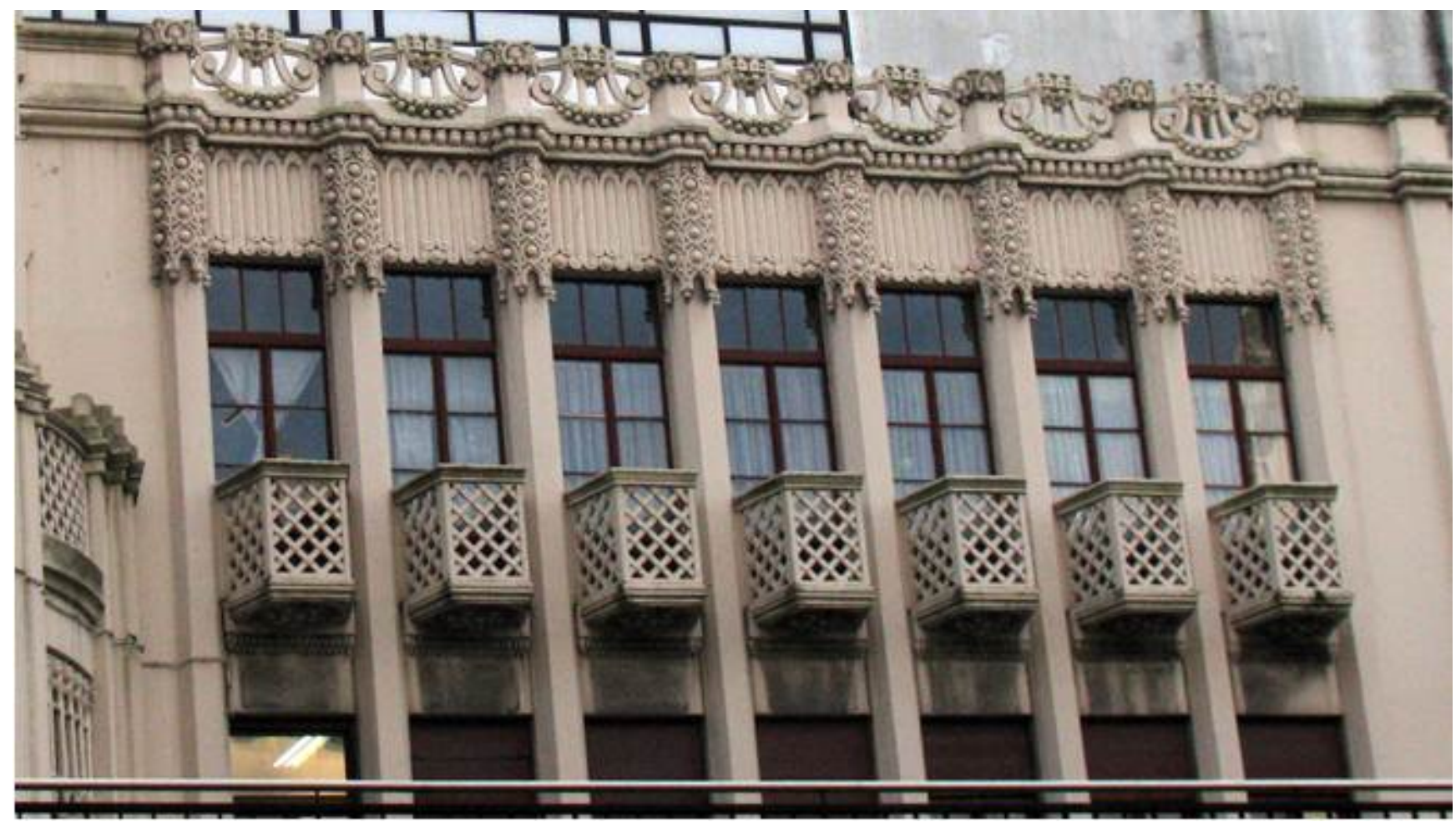

Built surfaces can be used as passive samplers that are permanently exposed to the pollution agents, allowing the study of the cumulative load up to the moment of sampling (see Figure 2), avoiding the problem of definition of time interval for collection of samples and that, depending on the processes of transport and fixation of pollutants would develop sequences of pollutants that could be studied by depth profiling (as has been classically done in the study of sedimentary sequences). Indoor and sheltered outdoor surfaces would be specially valued places where there would be cumulative 
absorption and dry deposition of pollutants without leaching. Sampling of products on surfaces of the built environment is generally possible, but sometimes restricted in terms of amounts (especially in the case of cultural heritage).

A general problem in the use of decay features is to define unequivocal relations between a given substance and a given source, including the distinction between contribution of exogenous agents and the substrate and distinction between different sources.

Regarding the characterization of the substances present in decay features, categorical and quantitative analytical studies can be performed. The expression "categorical analytical studies" is used here to represent all analytical studies whose result is placed in a given group, either as dichotomous presence/absence results, such as identification of compounds, or estimations that can be classified in ordered categories corresponding to different levels of abundance. Examples of dichotomous presence/absence studies are studies of identifications of substances by analytical methods such as x-ray diffraction, scanning electron microscopy and diverse spectroscopic techniques. The identified compounds can give information on the pollution sources and conditions using morphological, chemical and structural characteristics of particles [29,85,97] and the presence of specific substances such as organic compounds [98,99]. Isotopic signatures on living organisms [100] and mineral deposits $[29,101]$ can also be used to characterize the surrounding pollution (for example, Klemm and Siedel [101] refer to a trend towards higher $\delta^{34} \mathrm{~S}$ values with higher atmospheric pollution). A possible interesting application would be the fixation of radioactive isotopes on the substrates.

Spatial analysis of categorical studies, including the distribution of the frequency of decay features and identified substances, can help to assess regions with higher pollution load (concentration of occurrences of a given substance) on the presence of substances on decay features and might be useful in the screening and selection of locals for more detailed studies as well as definition of monitoring networks.

Quantitative analytical studies assess amounts of substances and could be used to compare samples of different regions, or different places in a built structure, or to compare the alteration features with the substrate $[99,102,103]$. One must be aware of the effect of differences in the length of exposure time and circumstances that might create diverse conditions of fixation, such as reactivity of substrates, environmental conditions and morphological aspects of buildings. To deal with these issues one can use normalization procedures such ratios to elements or ions of reference (using substances whose concentrations are considered to be unaffected by the presumed pollution sources) to compare contributions of possible pollution sources as well as the affected substrates [104,105]. Graphical procedures can also be used to compare elements or ions, considering possible mineralogical relations and signatures of pollution sources [106,107] and to classify atmospheric particles deposited on surfaces [108].

Besides the characterization of surfaces at any given time, longitudinal studies on cleaned materials can be of interest in the use of the built materials as records of pollution, following along the lines mentioned in the previous section. The study of the evolution of surfaces after cleaning might contribute to assess the persistence of pollution sources. In favorable conditions and depending on the time framework of interest, longitudinal studies of periodically cleaned surfaces might help to assess variations in time of the pollutants. 


\section{Conclusions}

As has been shown, several issues related to interactions between pollutants and surfaces of the built environment, both at any given moment and from a longitudinal perspective, can have relevance for environmental options and policies concerning aspects such as choices of materials and forms, consumption of resources, production and transport of pollutants, restrictions on activities and products and the assessment of pollution situations. This overview has also indicated some possible uses of built surfaces for monitoring of pollutants.

Based on the aspects presented in the previous sections, some recommendations potentially relevant for environmental management programs are proposed:

- To include assessments of the different impacts (substances and procedures in terms of consumption, release and restrictions) in the planning of interventions in the built environment (maintenance, conservation, restoration);

- To specify choices of materials and forms that minimize environmental impacts (considering both durability and impacts of extraction);

- To assess the performance of materials in the field in real structures and under real pollution conditions;

- To evaluate the effects of restrictions on activities on the effects of pollutants in the built environment;

- To develop criteria for acceptance of materials considering the risk of release of contaminants under the specific conditions of application of those materials;

- To promote the existence of architectural sheltered built elements that would be useful for the monitoring of atmospheric pollution;

- To consider a selection of surfaces that would be left unclean so as to be permanently available as records of pollution;

- To promote citizens sensibility to monitoring of visual changes in new or cleaned surfaces and its possible significance in terms of the conservation of the built environment and as evidence of pollution characteristics.

\section{Acknowledgements}

The Centre of Geological Research, Management and Valorisation of Resources (CIG-R) is supported by the Fundação para a Ciência e Tecnologia (Portugal) Portuguese funds (pluriannual funding program for research units, PEst-OE/CTE/UI0697/2011). The collaboration between the authors in this subjected has benefited from Portuguese-Spanish collaboration Project “Ação Integrada E-141/10" (Fundação das Universidades Portuguesas)/“Acción Integrada PT20090077” (Ministerio de Ciencia e Innovación). 


\section{References and Notes}

1. Fitzner, B.; Heinrichs, K. Damage diagnosis on stone monuments-Weathering forms, damage categories and damage indices. In Understanding and Managing Stone Decay; Prikryl, R., Viles, H.A., Eds.; The Karolinum Press: Prague, Czech Republic, 2002; pp. 11-56. Available online: http://www.stone.rwth-aachen.de/decay_diagnosis.pdf (accessed on 1 August 2010).

2. Amoroso, G.G.; Fassina, V. Stone Decay and Conservation: Atmospheric Pollution, Cleaning, Consolidation and Protection; Elsevier: Amsterdam, The Netherlands, 1983.

3. Winkler, E.M. Stone in Architecture. Properties, Durability; Springer-Verlag: Berlin, Germany, 1994.

4. Goudie, A.S.; Viles, H.A. Salt Weathering Hazard; John Wiley \& Sons: Chichester, UK, 1997.

5. Feist, W.C. Natural weathering of wood and its control by water-repellent preservatives. Am. Painting Contractor 1992, 69, 18-25.

6. Sandberg, D.; Söderström, O. Crack formation due to weathering of radial and tangential sections of pine and spruce. Wood Mat. Sci. Eng. 2006, 1, 12-20.

7. Trethewey, K.R.; Chamberlain, J. Corrosion for Science and Engineering; Longman Scientific and Technical: Harlow, UK, 1995.

8. Roberge, P.R. Handbook of Corrosion Engineering; McGraw-Hill: New York, NY, USA, 2000.

9. Tidblad, V.; Kucera, J. Air pollution damage to metals. In The Effects of Air Pollution on the Built Environment; Brimblecombe, P., Ed.; Imperial College Press: London, UK, 2003; pp. 227-247.

10. Delre, L.C.; Miller, R.W. Characterization of weather aging and radiation susceptibility. In Engineered Materials Handbook, Volume 2, Engineering Plastics; ASM International: Metals Park, OH, USA, 1988; pp. 575-580.

11. Seymour, R.B. Determination of chemical susceptibility. In Engineered Materials Handbook, Volume 2, Engineering Plastics; ASM International: Metals Park, OH, USA, 1988; pp. 571-574.

12. Lefèvre, R.A.; Chabas, A.; Munier, I.; Lombardo T. Modern and ancient glass in the polluted atmosphere. What is the prevailing phenomenon? Leaching, corrosion, soiling, encrusting...? In Cultural Heritage Conservation and Environmental Impact Assessment by Non-Destructive Testing and Micro-Analysis; Van Grieken, R., Janssens K., Eds.; Taylor \& Francis Group: London, UK, 2005; pp. 77-90.

13. Lombardo, T.; Ionescu, A.; Chabas, A.; Lefèvre, R.-A.; Ausset, P.; Candau, Y. Dose-response function for the soiling of silica-soda-lime glass due to dry deposition. Sci. Total Environ. 2010, 408, 976-984.

14. Koleske, J.V., Ed. Paint and Coating Testing Manual: 14th Edition of the Gardner-Sward Handbook; ASTM: Philadelphia, PA, USA, 1995.

15. Wypych, G. Handbook of Material Weathering; ChemTec Publishing: Ontario, Canada, 1995.

16. Eastaugh, N. The visual effects of dirt on paintings. In Dirt and Pictures Separated; In proceedings of The United Kingdom Institute of Conservation \& Tate Gallery Conference, London, UK, January 1990; The United Kingdom Institute for Conservation: London, UK, 1990; pp. 19-23. 
17. De Bock, L.A.; Van Grieken, R.E.; Camuffo, D.; Grime G.W. Microanalysis of museum aerosols to elucidate the soiling of paintings: Case of the Correr Museum, Venice, Italy. Environ. Sci. Technol. 1996, 30, 3341-3350.

18. Saunders, D. Pollution and the national gallery. National. Gallery. Technical. Bulletin. 2000, 21, 77-94.

19. Favrel, V.; Hecq, W. External costs of air pollution generated by road traffic in the Brussels urban area. IJVD 2001, 27, 129-139.

20. Watt, J.; Jarrett, D.; Hamilton R. Dose-response functions for the soiling of heritage materials due to air pollution exposure. Sci. Total Environ. 2008, 400, 415-424.

21. Arnold, A.; Zehnder, K. Monitoring wall paintings affected by soluble salts. In The Conservation of Wall Paintings; Getty Conservation Institute: Los Angeles, CA, USA, 1991; pp 103-135, Available online: http://getty.edu/conservation/publications/pdf_publications/wall_paintings.pdf (accessed on 1 January 2011).

22. Price, C.A. Stone Conservation: An Overview of Current Research; The J. Paul Getty Trust: Santa Monica, CA, USA, 1996. Available online: http://www.getty.edu/conservation/publications/ pdf_publications/stoneconservation.pdf (accessed on 1 January 2011).

23. Yoon, Y.H.; Brimblecombe, P. Contribution of dust at floor level to particle deposit within the Sainsbury Centre for Visual Arts. Stud. Conserv. 2000, 45, 127-137.

24. Camuffo, D.; Van Grieken, R.; Busse, H.-J.; Sturaro, G.; Valentino, A.; Bernardi, A.; Blades, N.; Shooter, D.; Gysels, K.; Deutsch, F.; Wieser, M.; Kim, O.; Ulrych, U. Environmental monitoring in four European museums. Atmos. Environ. 2001, 35, 127-140.

25. Steiger, W.; Dannecker, W. Determination of wet and dry deposition of atmospheric pollutants on building stones by field exposure experiments. In Proceedings of The III International Symposium on the Conservation of Monuments in the Mediterranean Basin, Venice, Italy, 1994; pp. 171-177.

26. Roberge, P.R.; Klassen, R.D.; Haberecht, P.W. Atmospheric corrosivity modeling-A review. Mater. Design 2002, 23, 321-330.

27. Sabbioni, C. Mechanisms of air pollution damage to stone. In The Effects of Air Pollution On The Built Environment; Brimblecombe, P., Ed.; Imperial College Press; London, UK, 2003; pp. 63-106.

28. Brimblecombe, P.; Grossi, C.M. Potential damage to modern building materials from 21 st century air pollution. TheScientificWorldJOURNAL 2010, 10, 116-125.

29. Nord, A.G.; Tronner, K.; Boyce, A.J. Atmospheric bronze and copper corrosion as an environmental indicator. A study based on chemical and sulphur isotope data. Water Air Soil Poll. 2001, 127, 193-204.

30. Mostafavi, M.; Leatherbarrow, D. On Weathering: The life of Buildings in Time; MIT Press: Cambridge, MA, USA, 1993.

31. Kirkwood, N. Weathering and Durability in Landscape Architecture: Fundamentals, Practices, and Case Studies; John Wiley \& Sons: Hoboken, NJ, USA, 2004.

32. Gorbushina, A. Life on the rocks. Environ. Microbiol. 2007, 9, 1613-1631.

33. Parnham, P. Prevention of Premature Staining of New Buildings; Taylor \& Francis: London, UK, 1997. 
34. Turkington, A.V.; Paradise, T.R. Sandstone weathering: A century of research and innovation. Geomorphology 2005, 67, 229-253.

35. Pye, K.; Schiavon N. Cause of sulphate attack on concrete, render and stone indicated by sulphur isotope ratios. Nature 1989, 342, 663-664.

36. Macleod, G.; Fallick, A.E.; Hall A.J. The mechanism of carbonate growth on concrete structures, as elucidated by carbon and oxygen isotope analyses. Chem. Geol. 1991, 86, 335-343.

37. Rafai, N.; Letolle, R.; Blanc, P.; Gegout, P.; Revertegat, E. Carbonation-decarbonation of concretes studied by the way of carbon and oxygen stable isotopes. Cem. Concr. Res. 1992, 22, 882-890.

38. Vallet, J.M.; Gosselin, C.; Bromblet, P.; Rolland, O.; Vergès-Belmin, V.; Kloppmann, W. Origin of salts in stone monument degradation using sulphur and oxygen isotopes: First results of the Bourges cathedral (France). J. Geochem. Explor. 2006, 88, 358-362.

39. Sanjurjo-Sánchez, J, Alves, C. Decay effects of pollutants on materials applied in the built environment. In Environmental Chemistry for A Sustainable World, Volume 2: Remediation of Air and Water Pollution; Lichtfouse. E., Schwarzbauer, J., Robert, D., Eds.; Springer: Berlin, Germany, 2011, pp. 47-121.

40. Lithgow, K.; Lloyd, H.; Brimblecombe, P.; Yoon, Y.H.; Thickett, D. Managing dust in historic houses-A visitor/conservator interface; In Proceedings 14th Triennial Meeting ICOM Committee for Conservation Triennial Meeting, The Hague, The Netherlands, 2005; Maney Publishing: London, UK, 2005; Vol. II, pp. 662-669.

41. Young, M.E.; Urquhart, D.C.M.; Laing, R.A. Maintenance and repair issues for stone cleaned sandstone and granite building façades. Build. Environ. 2003, 38, 1125-1131.

42. Warscheid, Th.; Braams, J. Biodeterioration of stone: A review. Int. Biodeterioration Biodegrad. 2000, 46, 343-368.

43. Silence, P. How are US conservators going green? Results of polling AIC members. Stud. Conserv. 2010, 55, 159-163.

44. Seaward, M.R.D. Lichens, agents of monumental destruction. Microbiology Today 2003, 30, 110-112.

45. Hayton, B. Sustainability and public museum buildings: The UK legislative perspective. Stud. Conserv. 2010, 55, 150-154.

46. O'Dwyer, D. The contribution of conservators to sustainability at the National Maritime Museum. Stud. Conserv. 2010, 55, 155-158.

47. Pio, C.A.; Ramos, M.M.; Duarte, A.C. Atmospheric aerosol and soiling of external surfaces in an urban environment. Atmos. Environ. 1998, 32, 1979-1989.

48. Flores-Colen, I.; de Brito, J. A systematic approach for maintenance budgeting of buildings facades based on predictive and preventive strategies. Constr. Build Mater. 2010, 24, 1718-1729.

49. Dorsey, J.; Hanrahan P. Digital materials and virtual weathering. Sci. Am. 2000, 282, 64-71.

50. Even, P.; Gobron S. Interactive three-dimensional reconstruction and weathering simulations on buildings. In Proceedings of the XXth international Symposia CIPA'05, Turin, Italy, 2005; pp. 796-801.

51. Gaylarde, C.C.; Morton, L. Deteriogenic biofilms on buildings and their control: A review. Biofouling: J. Bioadhesion Biofilm Res. 1999, 14, 59-74. 
52. Chew, M.Y.L.; Tan, P.P. Facade staining arising from design features. Constr. Build Mater. 2003, 17, 181-187.

53. Chew, M.Y.L.; Tan, S.S.; Kang, K.H. A technical evaluation index for curtain wall and cladding facades. Structural Survey 2004, 22, 210-227.

54. Flores-Colen, I.; de Brito, J.; de Freitas, V.P. Stains in facades' rendering-Diagnosis and maintenance techniques' classification. Constr. Build Mater. 2008, 22, 211-221.

55. Barberousse, H.; Lombardo, R.J.; Tell, G.; Couté, A. Factors involved in the colonisation of building façades by algae and cyanobacteria in France. Biofouling: J. Bioadhesion Biofilm Res. 2006, 22, 69-77.

56. Van der Sloot, H.A. Comparison of the characteristic leaching behavior of cements using standard (EN 196-1) cement mortar and an assessment of their long-term environmental behavior in construction products during service life and recycling. Cem. Concr. Res. 2000, 30, 1079-1096.

57. Townsend, H.E., Ed.; Outdoor Atmospheric Corrosion; STP 1421, ASTM International: West Conshohocken, PA, USA, 2002.

58. Heiss, K.; Skalli, M.; Zallmanzig, J. Diagnosis study of the St. Marienkirche, Lippstadt, a mediaeval greensandstone monument, for conservatory planning. In Science, Technology and European Cultural Heritage; Baer, N.S., Sabbioni, C., Sors, A.I., Eds.; Butterworth Heinemann: Oxford, UK, 1991; pp. 939-942.

59. Wüst, R.A.J.; Schlüchter, C. The Origin of soluble salts in rocks of the Thebes Mountains, Egypt: The damage potential to ancient Egyptian wall art. J. Archaeol. Sci. 2000, 27, 1161-1172.

60. Odler, I.; Hydration, setting and hardening of Portland cement. In Lea's Chemistry of Cement and Concrete; Hewlett, P.C., Ed.; Elsevier: Oxford, UK, 1998; pp. 241-297.

61. Netterberg, F.; Bennet, R.A. Blisteing and cracking of airport runway surfacing due to salt crystallization. In Proceedings of the 8th Conference on Asphalt Pavements for Southern Africa CAPSA'04, Sun City, South Africa, 12-16 September 2004; paper 088. Available online: http://www.capsa-events.co.za/capsa04/Documents/088.pdf (accessed on October 2010).

62. Cooper, T.P.; Dowding, P.; Lewis, J.O.; Mulvin, L.; O’Brien, P.; Olley, J.; O’Daly, G. Contribution of calcium from limestone and mortar to the decay of granite walling. In Science, Technology and European Cultural Heritage; Baer, N.S., Sabbioni, C., Sors, A.I., Eds.; Butterworth Heinemann: Oxford, UK, 1991; pp. 456-461.

63. Zannini, A.; Zambon, L.; Pagnin, P. Restoration of the "Vasca del Pincio" in Rome. In Science, Technology and European Cultural Heritage; Baer, N.S.; Sabbioni, C.; Sors, A.I., Eds.; Butterworth Heinemann: Oxford, UK, 1991; pp. 745-746.

64. Weaver, M.E. Acid rain and air pollution vs. the buildings and outdoor sculptures of Montreal. APT Bulletin 1991, 23, 13-19.

65. Haneef, S.J.; Dickinson, C.; Johnson, J.B.; Thompson, G.E.; Wood, G.C. Simulation of the degradation of coupled stones by artificial acid rain. Stud. Conserv. 1992, 37, 105-112.

66. Duffy, A.P.; O'Brien, P.F. A basis for evaluating the durability of new building stone. In Processes of Urban Stone Decay; Smith, B.J., Warke, P.A., Eds.; Donhead Publishing: London, UK, 1996; pp. 253-260.

67. Smith, M.R., Ed. Stone: Building Stone, Rock Fill and Armourstone in Construction; Engineering Geology Special Publications 16; Geological Society: London, UK, 1999. 
68. Figueiredo, C.A.M.; Aires Barros, L.; Basto, M.J.; Graça, R.C.; Maurício, A. The weathering and weatherability of Basílica da Estrela stones, Lisbon, Portugal. In Building Stone Decay: From Diagnosis to Conservation; Přikryl, R., Smith, B.J., Eds.; Special Publications, 271; Geological Society: London, UK, 2007; pp. 99-107.

69. Rodríguez Navarro, C.; Sebastián, E.; Rodríguez Gallego, M. An urban model for dolomite precipitation: Authigenic dolomite on weathered building stones. Sediment. Geol. 1997, 109, $1-11$.

70. Smith, B.J.; Turkington, A.V.; Warke, P.A.; Basheer, P.A.M.; McAlister, J.J.; Meneely, J.; Curran, J.M. Modelling the rapid retreat of building sandstones: A case study from a polluted maritime environment. In Natural Stone, Weathering Phenomena, Conservation Strategies and Case Studies; Siegesmund, G.S., Vollbrecht, A., Weiss T., Eds.; Special Publications 205; Geological Society: London, UK, 2002; pp. 347-362.

71. Lopez Arce, P.; Doehne, E.; Martin, W.; Pinchin, S. Magnesium sulfate salts and historic building materials: Experimental simulation of limestone flaking by relative humidity cycling and crystallization of salts. Materiales de Construcción 2008, 58, 125-142.

72. Benea, B. Representative stones and weathering forms at Histria Fortress, Romania. In Origin, Mechanisms, and Effects of Salts on Degradation of Monuments in Marine and Continental Environments; Zezza, F., Ed.; Protection and Conservation of the European Cultural Heritage Research Report No. 4; European Commission: Brussels, Belgium, 1996; pp. 205-216.

73. Robert, M.; Bernabe, E.; Bromblet, Ph.; Jaunet, A.M.; Verges Belmin, V.; Penven, M.J. Identification of two alteration microsystems chemical and physical, causing granite and kersantite degradation in Brittany (France). In Degradation and Conservation of Granitic Rocks in Monument; Vicente, M.A., Delgado Rodrigues, J., Acevedo, J., Eds.; Protection and Conservation of the European Cultural Heritage Research Report No. 5; European Commission: Brussels, Belgium, 1996; pp. 67-71.

74. Honeyborne, D.B. Weathering and decay of masonry. In Conservation of Building and Decorative Stone, Part I; Ashurst, J., Dimes F.G., Eds.; Butterworth-Heinemann: Oxford, UK, 1998; pp. 153-178.

75. Dreesen, R.; Nielsen, P.; Lagrou, D. The staining of blue stone limestones petrographically unravelled. Mater. Charact. 2007, 58, 1070-1081.

76. Bhargav, J.S.; Mishra, R.C.; Das, C.R. Environmental deterioration of stone monuments of Bhubaneswar, the temple city of India. Stud. Conserv. 1999, 44, 1-11.

77. Storemyr, P. Weathering of soapstone in a historical perspective. Mater. Charact. 2004, 53, 191-207.

78. Trujillano, R.; Iñigo, A.C.; Rives, V.; Vicente, M.A. Behaviour of three different types of granite under forced alteration. In Degradation and Conservation of Granitic Rocks in Monument; Vicente, M.A., Delgado Rodrigues, J., Acevedo, J., Eds.; Protection and Conservation of the European Cultural Heritage Research Report No. 5; European Commission: Brussels, Belgium, 1996; pp. 89-93.

79. Alonso, F.J.; Vázquez, P.; Esbert, R.M.; Ordaz, J. Ornamental granite durability: Evaluation of damage caused by salt crystallization. Materiales de Construcción 2008, 58, 191-201.

80. Lea, F.M. The Chemistry of Cement and Concrete; E. Arnold Publishers: London, UK, 1970. 
81. Hartog, P.; McKenzie, P. The effects of alkaline solutions on limestone. Discovering Stone 2004, $3,34-49$.

82. Dow, C.; Glasser, F.P. Calcium carbonate efflorescence on Portland cement and building materials. Cem. Concr. Res. 2003, 33, 147-154.

83. Anstice, D.J.; Page, C.L.; Page, M.M. The pore solution phase of carbonated cement pastes. Cem. Concr. Res. 2005, 35, 377-383.

84. Armstrong, R. Living technology for sustainable cities. News in Conservation 2010, 20, 4-5.

85. Del Monte, M.; Sabbioni, C. Gypsum crusts and fly ash particles on carbonatic outcrops. Arch. Meteor. Geophy. B 1984, 35, 105-111.

86. Heasman, I.; Watt, J. Particulate pollution case studies which illustrate uses of individual particle analysis by scanning electron microscopy. Environ. Geochem. Hlth. 1989, 11, 157-162.

87. Alves, C. "White" crusts on recent buildings. Mater. Sci. Forum 2010, 636-637, 1300-1305.

88. Arenas, C.; Osacar, C.; Sancho, C.; Vazquez-Urbez, M.; Auque, L.; Pardo, G. Seasonal record from recent fluvial tufa deposits (Monasterio de Piedra, NE Spain); sedimentological and stable isotope data. In Tufas and Speleothems: Unravelling the Microbial and Physical Controls; Pedley, H.M., Rogerson, M., Eds.; Geological Society Special Publications 336; Geological Society: London, UK, 2010; pp. 119-142.

89. Mattey, D.P.; Fairchild, I.J.; Atkinson, T.C.; Latin, J.-P.; Ainsworth, M.; Durell, R. Seasonal microclimate control of calcite fabrics, stable isotopes and trace elements in modern speleothem from St Michaels Cave, Gibraltar. In Tufas and Speleothems: Unravelling the Microbial and Physical Controls; Pedley, H.M., Rogerson, M., Eds.; Geological Society Special Publications 336; Geological Society: London, UK, 2010; pp. 323-344.

90. Adams, S.J.; Ford, D. Monitoring of deposited particles in cultural properties: The influence of visitors. Atmos. Environ.2001, 35, 4073-4080.

91. Gaspar, P.; de Brito, J. Mapping defect sensitivity in external mortar renders. Constr. Build Mater. 2005, 19, 571-578.

92. Camuffo, D.; Del Monte, M.; Sabbioni, C.; Vittori, O. Wetting, deterioration and visual features of stone surfaces in an urban area. Atmos. Environ. 1982, 16, 253-2259.

93. Girardet, F.; Furlan, V. Réactivité des pierres au $\mathrm{SO}_{2}$ atmosphérique, etude en chamber de simulation et correlation avec les mesures en site réel. In Proceedings of the 8th International Congress on Deterioration of Conservation of Stone, Berlin, Germany, 1996; Riederer, J., Ed.; pp. 341-347.

94. Gilbert, N.L.; Woodhouse, S.; Stieb, D.M.; Brook, J.R. Ambient nitrogen dioxide and distance from a major highway. Sci. Total Environ. 2003, 312, 43-46.

95. Janhäll, S.; Olofsson, K.F.G.; Anderson, P.U.; Pettersson, J.B.C.; Hallquist, M. Evolution of the urban aerosol during winter temperature inversion episodes. Atmos. Environ. 2009, 40, 5355-5366.

96. Taseiko, O.V.; Mikhailuta, S.V.; Pitt, A.; Lezhenin, A.A.; Zakharov, Y.V. Air pollution dispersion within urban street canyons. Atmos. Environ. 2009, 43, 245-252.

97. Sanjurjo-Sanchez, J.; Vidal Romani, J.R.; Alves, C. Deposition of particles on gypsum-rich coatings of historic buildings in urban and rural environments. Constr. Build Mater. 2010, 25, 813-822. 
98. Saiz-Jimenez, C. Deposition of airborne organic pollutants on historic buildings. Atmos. Environ. 1993, 27B, 77-85.

99. Sabbioni, C.; Ghedini, N.; Bonazza, A. Organic anions in damage layers on monuments and buildings. Atmos. Environ. 2003, 37, 1261-1269.

100. Winner, W.E.; Bewley, J.D.; Krouse, H.R.; Brown, H.M. Stable sulfur isotope analysis of $\mathrm{SO}_{2}$ pollution impact on vegetation. Oecologia 1978, 36, 351-361.

101. Klemm, W.; Siedel, H. Evaluation of the origin of sulphate compounds in building stone by sulphur isotope ratio. In Natural Stone, Weathering Phenomena, Conservation Strategies and Case Studies; Siegesmund, G.S., Vollbrecht, A., Weiss T., Eds.; Special Publications 205; Geological Society: London, UK, 2002; pp. 419-429.

102. Maravelaki-Kalaitzaki, P.; Biscontin, G. Origin, characteristics and morphology of weathering crusts on Istria stone in Venice. Atmos. Environ. 1999, 33, 1699-1709.

103. Valls del Barrio, S.; Garcia Valles, M.; Pradell, T.; Vendrell Saz, M. The red-orange patina developed on a monumental dolostone. Eng. Geol. 2002, 63, 31-38.

104. Sabbioni, C. Contribution of atmospheric deposition to the formation of damage layers. Sci. Total Environ. 1995, 167, 49-55.

105. Torfs, K.; Van Grieken, R. Chemical relations between atmospheric aerosols, deposition and stone decay layers on historic buildings at the Mediterranean coast. Atmos. Environ. 1997, 31, 2179-2192.

106. Begonha, A.; Sequeira Braga, M.A. Black crusts and thin black layers in granitic monuments: their characterization and the role of air pollution. In Proceedings of the 8th International Congress on Deterioration of Conservation of Stone, Berlin, Germany, 1996; Riederer, J., Ed.; pp. 371-375.

107. Begonha, A.; Sequeira Braga, M.A.; Gomes da Silva, F. Rain water as a source of the soluble salts responsible for stone decay in the granitic monuments of Oporto and Braga-Portugal. In Proceedings of the 8th International Congress on Deterioration of Conservation of Stone, Berlin, Germany, 1996; Riederer, J., Ed.; pp. 481-487.

108. Derbez, M.; Lefèvre, R.A. Le contenu microparticulaire des croûtes gypseuses de la Cathédrale Saint-Gatien de Tours: Comparaison avec l'air et la pluie. In Proceedings of the 8th International Congress on Deterioration of Conservation of Stone, Berlin, Germany, 1996; Riederer, J., Ed.; pp. 359-370.

(C) 2011 by the authors; licensee MDPI, Basel, Switzerland. This article is an open access article distributed under the terms and conditions of the Creative Commons Attribution license (http://creativecommons.org/licenses/by/3.0/). 